\title{
The church as sacrament of the kingdom - A reformed commentary
}

M E Brinkman ${ }^{1}$

(VU University Amsterdam)

\section{ABSTRACT \\ The church as sacrament of the kingdom - A reformed commentary}

One of the most promising aspects of the text of the third phase of the International Roman-Catholic-Reformed Dialogue might be the suggestion to reflect upon the idea of the church as "sacrament of the kingdom".

In this contribution, written in honour of the ecclesiological work of Conrad Wethmar, I shall take up that suggestion and develop a fourfold approach of the sacraments in which the interconnectedness of church and kingdom plays a crucial role. I shall deal with the soteriological, the ecclesiological, the eschatological and the symbolic aspect respectively. Deliberately, I begin with the soteriological aspect because the first and main thing sacraments are doing, is pointing to our salvation. Salvation implies, however, a mediation of salvation and hence the ecclesiological aspect follows the soteriological aspect. The mediation of the church always points beyond itself to the kingdom of God. That is the eschatological aspect. And every reference to the eschaton always has the form of the symbol as the focal point of the "already" and "not yet" character of the kingdom of God. We label that as the symbolic aspect.

My conclusion will be that the fruitfulness of the suggestion to speak about the church as "sacrament of the kingdom" depends on the preparedness to reap the results of the ecumenical discussions since Vatican II.

\section{SOTERIOLOGICAL ASPECT}

Time and again the recent document Church and Community of Common Witness to the Kingdom of God refers to the convergence reached between the Protestant emphasis on the church as creatura

1 Research Associate, Prof D E de Villiers, Department of Dogmatics and Ethics, University of Pretoria. 
verbi and the Roman Catholic emphasis on the church as sacramentum gratiae. The authors state that both visions are mutually informative and complementary and that neither is fully adequate without the other. "A "sacramental" church that does not give proper place to the Word of God would be essentially incomplete and a church that is truly a creation of the Word will celebrate that Word liturgically and sacramentally" (Reformed World 2007, 57:2-3, 193).

The so-called Lima text of the World Council of Churches gives a convincing example of the integration of words and their effects in the sacraments. It points especially to the rediscovery of the real meaning of the very concept of anamnesis, the commemoration of Christ's words and deeds and his death and resurrection. The biblical idea of commemoration refers to the present efficacy of God's work. It is not a simple calling to mind of what is past. It is the church's effective proclamation of God's mighty acts and promises in our history. The concept of anamnesis makes it impossible to fix the presence of Christ exclusively on the elements of bread and wine. It relates these elements to the content of the whole celebration of word and sacrament. To quote the Lima text: "Since the anamnesis of Christ is the very content of the preached Word as it is of the eucharistic meal, each reinforces the other” (Faith and Order Paper No.111 1982:12:E.12).

This emphasis on the interconnectedness of word and sacramental sign, provides the main requirements for overcoming the old controversy about the ex opere operato character of the sacraments. It means that we can refer to far more than only the effect of the sacraments by virtue of their performance. Protestants interpreted the Catholic affirmation of the ex opere operato as the affirmation of an automatic, salvific sacramental efficacy. And Catholics, conversely, saw the Protestant denial of the ex opere operato as a denial of the efficacy of sacraments in general. In the topical ecumenical dialogues, however, Catholics stress that the formula ex opere operato is actually intended to stress the fact that the divine offer of grace is in principle independent of the worthiness of the one administering the sacrament and the one receiving it. By defining Christ as the active subject of the sacrament, the tendency of the formula is to contradict any view which interprets the sacraments in the sense of a righteousness of works. Conversely, Protestants also stress that the sacraments depend for their existence 
on Christ's institution and are independent of the worthiness of the one administering them or the one receiving them. This acknowledgement, however, by no means implies that the sacraments have an automatic, magically ritual effect. The sacraments effect salvation only through faith, as the German Roman Catholic and Protestant dialogue partners stress in their common study entitled The Condemnations of the Reformation Era: Do They still Divide? (Lehmann and Pannenberg 1989:77-79).

\section{ECCLESIOLOGICAL ASPECT}

In the churches of the Reformation the concentration on Christ as the initiator and content of the sacraments has never led to a strong identification of church and Christ. Of course, one also spoke about the church as the body of Christ, but this ecclesiastical body was nevertheless strictly distinguished from Christ's own body. An instructive case in point is Barth's position. He underscores that the church as body of Christ is his "own earthly-historical form of existence". The church is entirely incorporated into Christ, but Christ is not entirely incorporated into his church (Barth 1961:643-725; 1967:614-655). Here is a close relation, but never an identification.

This strongly christological concept of the sacrament has been criticized by another Protestant theologian, also belonging to the Reformed tradition, namely Moltmann. A sacramental view of the church is only acceptable for him, if it is placed in the eschatological context of world history and is interpreted as an extension of the trinitarian sacraments of baptism and eucharist (Moltmann 1977: 199-206). His approach can be considered as a correction on the overly exclusive christological presuppositions of many Roman Catholic and Protestant ecclesiologies. The growing awareness of the role of the Spirit is indeed of paramount importance for an ecumenical understanding of the sacraments and of the church as sacrament. For the invocation of the Spirit in the celebration of the sacraments and the whole epicletical structure of the church manifest its essential and lasting dependence on God's gift that comes from "outside" and "above". It is part of the logic of such a sacramental concept of the church that the church in its human weakness must "incessantly pursue the path of penance and renewal" and be called to "continual reformation" (Lumen Gentium 8 and 48 and Unitatis Redintegratio 6). We hear in these quotations of texts from Vatican II a clear echo of the ecclesia semper reformanda, which was so strongly underscored by the Reformation churches (See short 
summary of the Roman Catholic view of the Church as sacrament in the above-mentioned sense, the text of the results of the international Roman Catholic-Lutheran dialogue in Church and Justification. Common Statement by the Lutheran-Roman Catholic Joint Commission, Geneva 1994:66-70).

By praying God to send down his Spirit, the church confesses that it does not have grace at its own disposal (see strong emphasis on the relation Spirit-Church, Van Eijk 1987:234-258). The church is sacrament as the body of Christ and as the temple of the Holy Spirit. In essence, Vatican II again calls to mind the classic patristic meaning of the use of the word "mystèrion" as qualification of God's salvation. It is the Spirit who lets us participate in the salvific work of Christ (see for a strong emphasis on the "instrument" and "service" character of the church also the text of the second phase of the International Reformed-Roman Catholic Dialogue, entitled "Towards a Common Understanding of the Church, "no 107). It states that words like sacrament and symbol "depict the Church as instrument and minister of the unique mediation of Christ. Of this unique mediation the Church is the servant, but never either its source or its mistress”.

It is especially here that Rahner's (1984:411-430) distinction between Jesus Christ as original sacrament ("Ursakrament”) and the church as basic sacrament ("Grundsakrament") turns out to be important. Jesus is the origin (origo) and the church derives its identity exclusively from this origin.

Vatican II calls the church sacrament in view of its role as a unifying symbol. In the unity of the church the divine destination for the whole of humanity becomes manifest. The church as sacrament is the symbol of that one destination. The integration of new insights in the theory of the meaning of symbols can be fruitful here. Terms like sacrament and symbol, as many contemporary authors endorse, designate the church as simultaneously the place of presence and of distance, of disclosure and disguise (see "Towards a Common Understanding of the Church", no 107). The dialogue text refers here to one of the publications of the French ecumenical dialogue group Groupe des Dombes (1979:23-24). In its turn this dialogue group may be inspired by the dialectic interpretation of the meaning of symbols by the French Protestant philosopher, Ricoeur (1976:17). This dialectics has been elaborated also in the sacramentology by French 
Roman Catholic theologian L-M Chauvet (1979:77-79; 91-93 and 1988:85-115).

Symbolic representation lies between commemoration (anamnesis) of the past (the saving work of Christ) and the expectation of the future (his coming in glory). In this way the Christian symbols signify an absence, and only in this way do they evoke a presence. This non-identity refers to the radical difference or Otherness (transcendence) of the Risen One. The resurrection teaches us that Christ is never simply at our disposal. It is especially this view which is confirmed by the resurrection-narratives that witness to the experiences both of grief over a loss (absence) and of rejoicing over a new experience of presence, mediated by the symbols of bread and wine (see for an elaboration of this view, Van Eijk 1987:246-247; 250).

In spite of the apparent ecumenical convergence on this christological-pneumatological application of the word sacrament to the church, the increasing inclination in Recent Roman Catholic documents to place the guarantee of this sacramentality in the "fullness of the sacrament of Orders", which according to Lumen Gentium 21 means: in the ministry of the bishops, can be considered as a remarkable development. The argument then runs as follows: Christ's presence in the church is guaranteed by the Apostles and their successors, the bishops. They are the guarantee that in the sacraments of baptism and eucharist the salvific meaning of Christ's death and resurrection is effectively mediated to us. As a matter of fact, this argumentation implies that the sacramentality of the church depends on the sacramentality of the ministry which is said to "participate" in that sacramental dimension (see the Roman Catholic reaction to the Lima-text, Thurian 1988:26, 29, 33 and 34).

Although the Reformation certainly considered the right administration of word and sacrament as characteristic of the true church and, therefore, certainly applied a criterion of "unbroken" continuity with regard to the sacraments, it was primarily concerned with the content of the theology of baptism and the Lord's Supper. Hence, in the present ecumenical dialogue the primary starting point has been the agreement in the field of a baptismal and eucharistic theology. For many Protestants, then, it comes as a surprise to learn that for the Roman Catholic Church, and indeed also for the Orthodox Church, this is only half the story. By so explicitly assigning "pride of place" to the ministry of the bishop and by 
relating this ministry so closely to the sacramentality of the church, Vatican II, in Van Eijk's view, goes much further than the Tridentine Council, which took only a historical argument as its starting-point for the explanation of the institution of the ministry of the bishop (The Church Teaches. Documents of the Church in English Translation 1973:329-332. See also Van Eijk 1991:352-367).

It will be evident that this kind of identification of the ministerial structure of the church and its sacramental character cannot easily be brought in convergence with the achievements of the above-mentioned modern theories of symbolism with their emphasis on a pneumatological dialectic of absence and presence, as developed by a great number of post-Vatican Catholic theologians and as articulated by the official Roman Catholic participants in, for example, the international Reformed-Roman Catholic dialogue. Therefore, there is in principle a considerable ecumenical convergence with regard to the emphasis on the sacramentality of the church in the texts of Vatican II, but the tendency to identify one ministerial structure of the church with this sacramentality seems to hinder more progress in unity in several international ecumenical dialogues (see for example the official Roman Catholic response to the final report of ARCIC I 1991, in Hill \& Yarnold 1994:156-166).

\section{ESCHATOLOGICAL ASPECT}

It was especially the rediscovery of the theology of the kingdom of God in the present century which freed the sacrament from the chains of "salvation individualism". Sacraments are primarily signs of the kingdom, as many authors have indicated in recent decades. This aspect is however not a modern one. Aquinas spoke already about sacraments as signa prognostica, as signs of the coming kingdom (Summa Theologiae, III, q.60 a.3, 862).

They are signs of the eschatological meal, anticipations of the kingdom of peace and justice. It was especially in liberation theology that this aspect was given a strong emphasis. By placing sacramentality in the horizon of the kingdom of God, the theology of liberation returns to the biblical and earliest historical origins of the mystery-sacrament.

As has already been mentioned, the essence of the mystery is God's will for salvation. This mystery is specifically the Kingdom of God. Thus, the theology of liberation reassumes the personalistic, christological, and ecclesiological horizon in the broader perspective 
of the Kingdom of God. There is indeed a "costly unity" between the church's sacramental and ethical orientation. This unity concerns the question to what extent Christians succeed in deriving a credible and authentic Christian profile from their baptismal vows, so that their communities may radiate something of the coming kingdom of God in our present cultures. Hence, questions of faith and social questions are inseparable from the act of Christian witness that baptism mandates.

The same applies to the eucharist. The eucharist as sacrament of communion is real food for scattered people in their social struggle, to heal the brokenness of human existence. In this way the church shares the real bread of life (Best \& Granberg-Michaelson 1993:89; Brinkman 1999:91-100).

As anticipatory, mediating signs of reconciliation sacraments are at the same time symbols of protest serving to unmask the life that is not yet reconciled. For Schillebeeckx (1980:768) this protest character of the sacraments is an indication that in Christian symbolic action there lies a "powerful historical potential which can integrate mysticism and politics".

Christian presence and action in a society in need of change, especially in the interest of the poor, emerges as a sacramental question. Prophetic in its action, the church has to be prophetic in its ritual. The recent document Church as Community stresses the anticipatory character of the Holy Communion by calling it "a foretaste of the heavenly banquet in the kingdom to come” (no 171).

\section{SYMBOLIC ASPECT}

The element of societal and communal relevance emerges not only in the eschatological aspect, but also in the accentuation of the symbolic aspect. Both accentuations share the common characteristic that the emphasis on the church and on the individual believer shift towards the social and communal aspect of the sacrament. In the eschatological aspect the socio-critical role of the sacraments finds expression, while in the symbolic aspect the communal role comes to the fore. The accentuation of the symbolic aspect essentially involves two elements. On the one hand, there is the rediscovery of the symbolic aspect of the sacramental element in the narrowest sense of the word, namely, the material element. On the other hand, there is the rediscovery of the symbolic aspect in the ritual, liturgical, sacramental act. 
The renewed attention to the material aspect of in particular the sacrament of baptism and of eucharist, chiefly concerns the transparency of all earthly things. What matters in that transparency is the way sacraments express the interplay among human beings, the world, and God. Sacramentology has to deal with this interplay.

In the emerging enculturation of Christian worship in Latin America, as well as in Africa and Asia, we can observe a basic sacramentality that relates to the religious sense inherent in cultures, and expresses humanity's relation to earth and cosmos. This approach can be labelled as the method of contextualisation (Power, Duffy \& Irwin 1994: 657-705).

Through this method it is possible to discover the role of rite in transforming the human and to discern ways of integrating cultural ritual forms into the proclamation of the meaning of the words and deeds of Jesus Christ in the world.

\section{CONCLUSION}

An ecumenist is perhaps more tempted than anybody else to focus his or her entire attention on the exegetical and historical debate about the sacraments. Most texts of ecumenical discussions between the great church traditions consist almost entirely of exegetical and historical expositions. This, however, is a dangerous pitfall. The exegetical and historical argumentation is of course of great importance in the ecumenical debate. Nevertheless, it would be an underestimation of our ecumenical task, if we engage only in an exegetical and historical debate. This would not in any way suffice to demonstrate the relevance of the church as sacrament of the kingdom in our present-day culture. In the eyes of many people, the sacraments have been reduced to clerical instruments of power. The influential French-speaking ecumenical working group, Groupe des Dombes (1997:33-34) displayed a great sense of reality on this point.

There is no doubt that this negative image of the sacraments is closely related to the fact that the discussion about the sacraments has been often narrowed down to the question of purity, and that of validity. It will be evident, however, that a theologically correct discussion of the validity of the sacraments has not yet said anything about their relevance. That relevance can be demonstrated only when the sacraments clearly express the meaning of the central message of the church for modern humanity in its concrete situation, and when 
the form of the sacraments as ritual symbols in the culture in which we live retains, or regains, its power of expression.

Without pretending to be able to overcome all the historical divergencies in a balanced definition of the sacraments, it is worthwhile to underscore that every definition should always retain the right balance between the four aspects mentioned here, without assigning a monopoly position to any of the four aspects. All these aspects need one another.

For example, a soteriological approach of the sacraments elucidates the salvific meaning of the sacraments, but cannot explain why we need the sacraments, apart from the preaching of the salvific meaning of the word of God. In other words: focusing on the theological content of the sacraments is extremely meaningful and necessary, but, as such, it cannot provide a sufficient argument for the necessity of the sacrament as a liturgical symbol. Its content may, for example, also be expressed by preaching.

An ecclesiological approach of the sacraments elucidates the question of the ecclesial mandate, as well as the fact that the administration of sacraments always concerns the community and the ecclesial fellowship. The sacrament is thoroughly bound up with the divine promise that God will not abandon his church. That proximity is transmitted by concrete persons who share, preserve and represent this promise. The recognition of this aspect of continuity and community is indispensable for the celebration of the sacraments. Without authorised ministers as representatives of Christ's promise to be with us, the sacraments lack their commonly shared historical dimension.

An exclusively ecclesiological approach of the sacraments, however, would detract us from the liberating and reconciling content of the sacraments. Of course, the question of the ecclesial setting of the sacraments is an extremely important one. Nevertheless, in comparison with the necessary emphasis on the liberating content of the sacraments, this ecclesial aspect remains a question of the second order. Referring to Vatican II's statement on a "hierarchy of truths", therefore Rahner (1984:324) can state: "The doctrine of the church is not the central truth of Christianity".

The sacrament is primarily aimed at the salvation of the faithful and, through them, at the salvation of the whole world. This is the "propter homines" aspect which Schillebeeckx (1980) always 
emphasised so strongly. The function of the sacraments is the concrete manifestation of that salvation. The church as institute constitutes the fruitful foundation for these symbols of salvation and may therefore itself also be called sacrament in a derived sense (veluti sacramentum!). The church is, therefore, rather a tertium, an institute which creates appropriate conditions in between Christ and the sacramental symbolic acts, as a kind of conditio sine qua non, continuously inspired by the Holy Spirit.

It is especially the eschatological dimension of the sacraments which confronts us with the broad outlines of God's salvation. God's salvation transcends the walls of the church and is aimed at the coming of God's kingdom. The church is sign and instrument of this salvation demonstrated in the sacraments. An exclusively eschatological approach of the sacrament would pay insufficient attention to the question of mediation. Insufficient emphasis on the eschatological aspect, however, would restrict us far too much to ecclesiastical or clerical territory, overshadowing the whole purpose which is the basis of all our sacramental aspirations, namely, to quote Irenaeus, the gloria dei and the vivens homo!: "Gloria enim Dei vivens homo, vita autem hominis visio Dei” (Irenaeus IV, 20, 7:1057).

A symbolic approach of the sacraments elucidates the sacraments as symbols of nature or as anthropological phenomenona. Of course, the sacraments cannot exist without these symbolic components. These basic components have been neglected far too long. The symbolic components bring us in touch with the earth as God's creation. They teach us how the earth is also included in God's salvation. And it is precisely the material aspect of the sacrament which confronts us with the "hard" and "realistic" aspects of Christ's death and resurrection. His life, death and resurrection are also a matter of flesh and blood. It touches our bodily existence in its centre. And it is not only in the materiality of our existence that a point of contact can be found. Such a point of contact is also to be found in the basic acts of human behaviour, in washing, sharing, drinking and eating. Hence, the sacraments touch not only the most fundamental material constitutive elements of our existence, but also the most fundamental human acts of our existence. Symbols are never isolated, individualistic acts, but are always embedded in social structures and recognised by a community. 
Therefore, the sacraments need all four aspects: the true-to-life relation in the symbolic aspect; the church-transcending proclamation of the kingdom of God in the eschatological aspect; the communion and continuity with all the witnesses of this gospel around and before us in the ecclesiological aspect; and the concentration on the salvific meaning of Christ's death and resurrection for our daily life in the soteriological aspect. This fourfold definition can be considered as a modern interpretation of Aquinas' classic threefold distinction between the sacrament as signum rememorativum, signum demonstrativum and signum prognosticum. The signum rememorativum point to the passio christi, eucharistic anamnesis, to the actualising memory of Christ's life, death and resurrection, namely the soteriological aspect. The signum demonstrativum points to the visible effect of this grace, mediated by the Church and symbolised in the sacraments, being the ecclesial and symbolic aspect. And the signum prognosticum points to the futura gloria, that is the eschatological aspect (Summa Theologiae III, q.60 a.3, 862).

These four aspects belong together, but the greatest of these is the eschatological one, is our expectation that through all our human acts and through all the elements of the earth and through the service of the church, God will be all in all. For the time being, the church is, therefore, predominantly sacrament of the kingdom of God.

\section{Consulted literature}

Baptism, Eucharist and Ministry (Faith and Order Paper No.111), 1982. Geneva.

Barth, K 1961. Church Dogmatics, IV/1. Edinburgh.

-, 1967. Church Dogmatics, IV/2. Edinburgh.

-, s.a. Summa Theologiae III. Edinburgh.

Best, Th F \& Granberg-Michaelson, W (eds) 1993. Costly Unity. Koinonia and Justice, Peace and Creation. Geneva.

Brinkman, M E 1995. Progress in Unity? Fifty Years of Theology within the World Council of Churches: 1945-1995. Louvain.

-, 1999. Sacraments of Freedom. Ecumenical Essays on Creation and Sacrament - Justification and Freedom (IIMO Research Publication 48). Zoetermeer.

Chauvet, L-M 1979. Du symbolique au symbole. Essai sur les Sacrements. Paris.

-, 1988. Symbole et sacrement. Une relecture sacramentelle de l'existence chrétienne. Paris. 
Church and Justification. Common Statement by the Lutheran-Roman Catholic Joint Commission 1994. Geneva.

Groupe des Dombes 1979. L'Esprit Saint, l'Église et les Sacrements. Taizé.

Hill, C \& Yarnold, E (eds) 1994. Anglicans and Roman Catholics: The Search for Unity. London.

Irenaeus, Adversus Heareses, IV, 20, 7: 1057.

Lehmann, K and Pannenberg, $\mathrm{W}$ (eds) 1989. The Condemnations of the Reformation Era: Do They Still Divide? Minneapolis.

Moltmann, J 1977. The Church in the Power of the Spirit. A Contribution to Messianic Ecclesiology. New York / London.

Power, D N, Duffy, R A \& Irwin, K W 1994. Current Theology: Sacramental Theology. A Review of Literature, Theological Studies 55, 657-705.

Rahner, K 1984. Foundations of Christian Faith. An Introduction to the Idea of Christianity. New York.

Ricoeur, P 1976. Symbols of Evil. London.

The Church Teaches. Documents of the Church in English Translation 1993. Rockford, 329-332.

Schillebeeckx, E 1980. Christ: The Experience of Jesus as Lord. New York.

Thurian, M (ed) 1988. Churches Respond to BEM, VI (Faith and Order Paper No.144). Geneva.

Van Eijk, A H C 1987. The Church as Sacrament. A Contribution to Ecumenical Understanding, Bijdragen 48, 234-258.

-, 1991. Ordained Ministry: Divine Institution and Historical Development. Reflections on a Roman Catholic Response to the Lima Report, One in Christ 27, 352-367. 